\title{
Chamber Size Effects on Methane Emissions from Rice Production
}

\author{
Alden D. Smartt1, Kristofor R. Brye1, Christopher W. Rogers², Richard J. Norman'1, \\ Edward E. Gbur ${ }^{3}$ Jarrod T. Hardke ${ }^{4}$, Trent L. Roberts ${ }^{1}$ \\ ${ }^{1}$ Department of Crop, Soil, and Environmental Sciences, University of Arkansas, Fayetteville, USA \\ ${ }^{2}$ Department of Plant, Soil, and Entomological Sciences, University of Idaho, Aberdeen, USA \\ ${ }^{3}$ Agricultural Statistics Laboratory, University of Arkansas, Fayetteville, USA \\ ${ }^{4}$ Department of Crop, Soil, and Environmental Sciences, University of Arkansas, Stuttgart, USA \\ Email: kbrye@uark.edu
}

Received 11 September 2015; accepted 16 October 2015; published 19 October 2015

Copyright (C) 2015 by authors and Scientific Research Publishing Inc.

This work is licensed under the Creative Commons Attribution International License (CC BY).

http://creativecommons.org/licenses/by/4.0/

(c) (i) Open Access

\section{Abstract}

Quantifying methane $\left(\mathrm{CH}_{4}\right)$ emissions from cultivated rice (Oryza sativa L.) production in the field has received increased attention recently due to methane's importance as a greenhouse gas. The enclosed-headspace chamber technique is the standard methodology for field assessments of trace gas emissions. However, to our knowledge, no direct comparisons of measured $\mathrm{CH}_{4}$ fluxes and emissions from field-grown rice among differing chamber sizes have been reported. Therefore, the objective of this study was to evaluate the effect of chamber size [15.2- and 30.4-cm inside diameter (id)] on $\mathrm{CH}_{4}$ fluxes and season-long emissions from rice grown on a clay soil in Arkansas. Chamber size did not affect $(P>0.05) \mathrm{CH}_{4}$ fluxes on 10 sampling dates during the flooded portion of the rice growing season and only affected fluxes on one of four sampling dates after flood release. Total season-long $\mathrm{CH}_{4}$ emissions from optimally $\mathrm{N}$-fertilized rice were 32.6 and $35.6 \mathrm{~kg}$

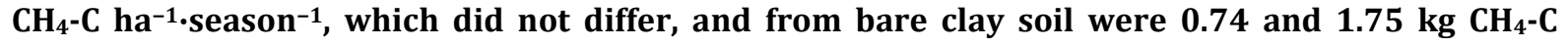
ha $^{-1} \cdot$ season $^{-1}$, which also did not differ, from the 15.2- and 30.4-cm chambers, respectively. Chamber size (i.e., 15.2 - or $30.4-\mathrm{cm}$ id) did not result in differences in cumulative $\mathrm{CH}_{4}$ emissions from this flooded-rice study that was conducted on a Sharkey clay soil in northeast Arkansas. Results indicate that both 15.2 - and $30.4-\mathrm{cm}$ diameter chambers were similarly adequate for measuring $\mathrm{CH}_{4}$ fluxes and emissions from the clay soil investigated. The similarity in emissions results between chamber sizes also indicates that the $15.2-\mathrm{cm}$ diameter chambers adequately facilitated the quantification of $\mathrm{CH}_{4}$ emissions in this study.

\section{Keywords}

Methane Emissions, Rice Production, Clay Soil, Arkansas 


\section{Introduction}

Rice (Oryza sativa L.) is one of the main staple food crops for much of the world's population, with direct human consumption accounting for $85 \%$ of rice production compared to $72 \%$ and $19 \%$ for wheat (Triticum aestivum L.) and maize (Zea mays L.), respectively [1]. However, globally, agriculture accounts for $47 \%$ of total anthropogenic methane $\left(\mathrm{CH}_{4}\right)$ emissions, with $64 \%$ and $22 \%$ of agricultural $\mathrm{CH}_{4}$ emissions resulting from enteric fermentation and rice cultivation, respectively [2] [3]. Agricultural activities account for $33 \%$ of $\mathrm{CH}_{4}$ emissions in the United States (US), of which enteric fermentation is responsible for approximately $70 \%$ and rice cultivation is responsible for 3.7\% [4]. Methane emissions from cultivated agricultural activities are significant since $\mathrm{CH}_{4}$ is a greenhouse gas and has a global warming potential that is 25 times greater than that of $\mathrm{CO}_{2}$ [5].

For field assessments of trace gas emissions, the enclosed-headspace chamber technique is the standard methodology [6] [7]. Livingston and Hutchinson [6] suggested that chamber areas typically range from $175 \mathrm{~cm}^{2}$ [i.e., 15.2-cm inside diameter (id)] to $1 \mathrm{~m}^{2}$, and that chamber areas of 500 to $900 \mathrm{~cm}^{2}$ (i.e., 25- to 34-cm id, respectively) are most common. The 15.2-cm id has also been suggested as the minimum chamber size to use in assessing trace gas emissions [7]. Thus, there is clearly no uniform chamber size associated with the enclosedheadspace chamber technique.

Recently, several field studies have used multiple chamber diameters to quantify $\mathrm{CH}_{4}$ emissions. Denier van der Gon et al. [8] used 20-cm diameters chambers to assess $\mathrm{CH}_{4}$ emissions from a clay soil in a pot study at the International Rice Research Institute in the Philippines. Rogers et al. [9] used 15.2-cm diameter chambers in a field study on a silt-loam soil in central Arkansas. Rogers et al. [10] used 30.4-cm diameter chambers in a field study on a similar silt-loam soil in central Arkansas. Simmonds et al. [11] used 30-cm diameter chambers on a silt-loam soil in central Arkansas and a silty-clay in California.

For a variety reasons, there is potential for variation in chamber diameters used in the field for quantifying trace gas emissions. Resource limitations may require smaller chambers to be constructed. Logistics of the crop to be studied and field installations may necessitate the use of smaller-diameter chambers. In particular, if studies are interested in differentiating between in-row and between-row emissions, then chamber diameter may be limited by plant spacing [9]. Statistical considerations may dictate larger chambers as larger chambers tend to mask spatial variability by integrating measurements over a larger soil area [6] [7]. Smaller chambers may be desirable in studies examining environmental gradients [6] [7].

Though there are a number of reasons for potential chamber-diameter variations, to our knowledge, no direct comparisons of measured $\mathrm{CH}_{4}$ fluxes and emissions from field-grown rice among differing chamber sizes have been reported. Therefore, the objective of this study was to evaluate the effect of chamber size (15.2- and 30.4$\mathrm{cm}$ id) on $\mathrm{CH}_{4}$ fluxes and season-long emissions from rice grown on a clay soil in Arkansas. It was hypothesized that $\mathrm{CH}_{4}$ fluxes would be more variable from the $15.2-\mathrm{cm}$ chamber due to the smaller footprint, thus differences in fluxes between chamber sizes would likely not be measured, but that season-long emissions would be greater from the 30.4-cm chamber due to the greater potential for microsite inclusion in the larger area.

\section{Materials and Methods}

\subsection{Site Description}

A field research study was conducted throughout the 2012 rice growing season (i.e., April to September) at the University of Arkansas System Division of Agriculture Northeast Research and Extension Center in Keiser, Arkansas $\left(35^{\circ} 40^{\prime} \mathrm{N} 90^{\circ} 05^{\prime} \mathrm{W}\right)$. The soil throughout the study area was mapped as a Sharkey clay (very-fine, smectitic, thermic Chromic Epiaquerts) [12], which was derived from alluvial sediments in the lower Mississippi River flood plain, and has been in a rice-soybean [Glycine max (L.) Merr.] rotation for $>25$ years. The mean annual air temperature throughout the region is $15.5^{\circ} \mathrm{C}$ and the mean annual precipitation is $126 \mathrm{~cm}$ [13].

\subsection{Treatments and Experimental Design}

Small (15.2-cm id) and large (30.4-cm id) chambers were installed in replicated plots ( $\mathrm{n}=4$ per treatment combination) containing optimally nitrogen (N)-fertilized rice and no rice (i.e., bare soil). A randomized completed block (RCB) split-plot design was used, with the whole-plot factor being vegetation (i.e., rice or no rice) and the split-plot factor being chamber size (i.e., 15.2- or 30.4-cm). Sample date (i.e., time) was also treated as a repeated measure since flux measurements were made periodically throughout the growing season. 


\subsection{Field and Plot Management}

Crop residues were incorporated by disking to a depth of $\sim 15 \mathrm{~cm}$ followed by land planing the previous fall to prepare the seed bed. Plots (1.6 m wide by $5.0 \mathrm{~m}$ long) were seeded at an $18-\mathrm{cm}$ row spacing with the standard stature, pure line, long-grain rice cultivar 'Taggart' at a rate of $112 \mathrm{~kg} \cdot \mathrm{ha}^{-1}$, which resulted in nine rice rows per plot. This cultivar was used due to its frequent use throughout the region at the time and its high yield potential [14]. Based on 18-cm row spacing and the surface area enclosed by each chamber, 10 and $40 \mathrm{~cm}$ of total row length of plants were included in the small $(15.2-\mathrm{cm}$ id) and large chambers (30.4-cm id), respectively, in order to duplicate the plant density of the field plots in both chamber sizes.

After planting, levees were constructed to create a single bay of rice when the permanent flood was established at the 4 - 6 leaf stage. Nitrogen, in the form of urea $(46 \% \mathrm{~N})$, was hand applied to individual vegetated plots only at $150 \mathrm{~kg} \mathrm{~N} \mathrm{ha}^{-1}$ one day prior to flood establishment [15]. A typical mid-season split application of $50 \mathrm{~kg} \mathrm{~N} \mathrm{ha}^{-1}$ as urea was made at the beginning of internode elongation to the vegetated plots only. A 5 to $10 \mathrm{~cm}$ flood depth was maintained throughout the growing season. Table 1 summarizes the dates of major agronomic activities that occurred in the field.

\subsection{Methane Sampling and Analysis}

A methodology using enclosed-headspace gas sampling chambers [6] [7] was used in this study. Similar field methods have been used previously in Arkansas [9] [10].

Small (15.2-cm id) and large (30.4-cm id) base collars (30 cm tall), extensions (40 and $60 \mathrm{~cm}$ long), and caps (10 cm tall) were constructed out of Schedule 40 polyvinyl chloride (PVC) pipe (Figure 1). Base collars were beveled to a $45^{\circ}$ angle on the bottom to facilitate installation into the soil and had four $12.5-\mathrm{mm}$ holes drilled just above the soil surface to allow water movement into and out of the base collar. After flood release, the holes were plugged with gray butyl-rubber septa (Voigt Global, part \# 73828A-RB, Lawrence, KS) during sampling. To accommodate the growth of the rice plants over the course of the growing season, chamber extensions of varying lengths were used to adjust the chamber height. To minimize temperature fluctuations inside the chambers, chamber extensions and caps were covered with reflective aluminum tape (CS Hyde, Mylar metalized tape, Lake Villa, IL). Chamber extensions were secured to base collars using sections of tire inner tube.

Chamber caps had a 5-mm thick flat sheet of PVC glued to the top with a 15-cm section of 4.5-mm id copper tubing installed in the side of each cap as a vent. Gray butyl-rubber septa were installed into 12.5-mm holes drilled in the top of each cap to serve as a sampling port and a port for measuring the temperature inside the chamber. A 2.5-cm diameter, 9-V battery-powered fan was also installed on the underside of each cap to mix the headspace inside the chamber. Sections of tire inner tube were also used to secure the caps to the extensions. To minimize soil disturbance after the flood was established, wood planking was installed on concrete blocks for access to all chambers in the field plots. The base collars were installed one week prior to sampling, just after initiating flood establishment.

Table 1. Summary of dates for major agronomic field activities involved in the management of methane emissions plots for the 2012 rice growing season at the University of Arkansas System Division of Agriculture Northeast Research and Extension Center in Keiser, Arkansas.

\begin{tabular}{cc}
\hline Field Activity & Date \\
\hline Planting & 2 April \\
Emergence & 30 April \\
Pre-flood Fertilizer Application & 7 June \\
Flood Establishment & 8 June \\
Mid-season Fertilizer Application & 10 July \\
Flood Release & 23 August \\
Harvest & 11 September \\
\hline
\end{tabular}




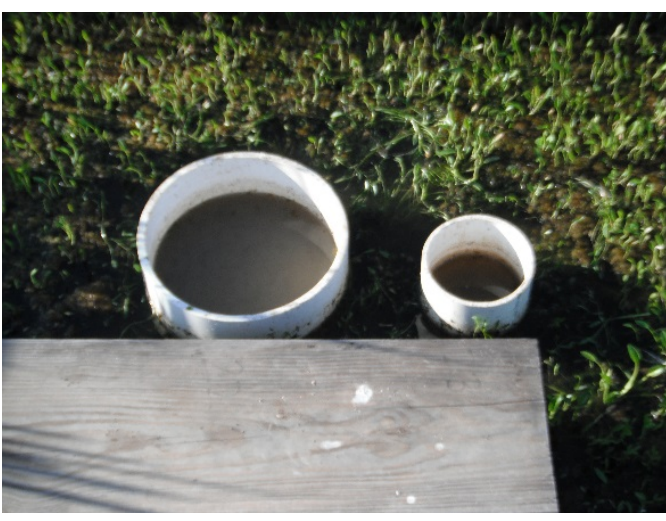

(a)

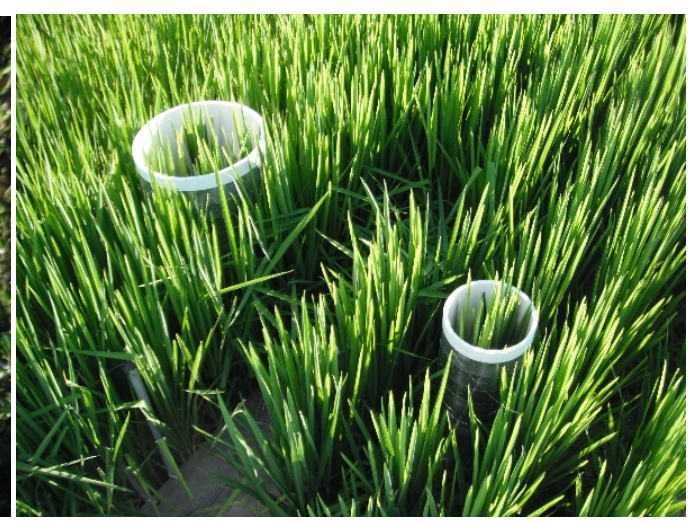

(b)

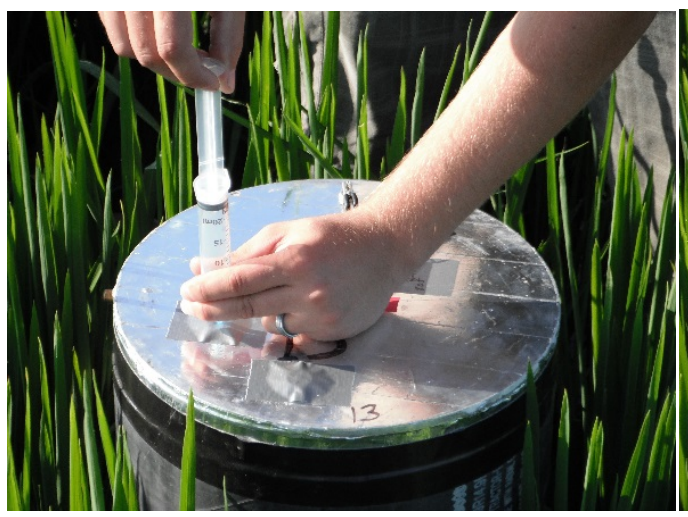

(c)

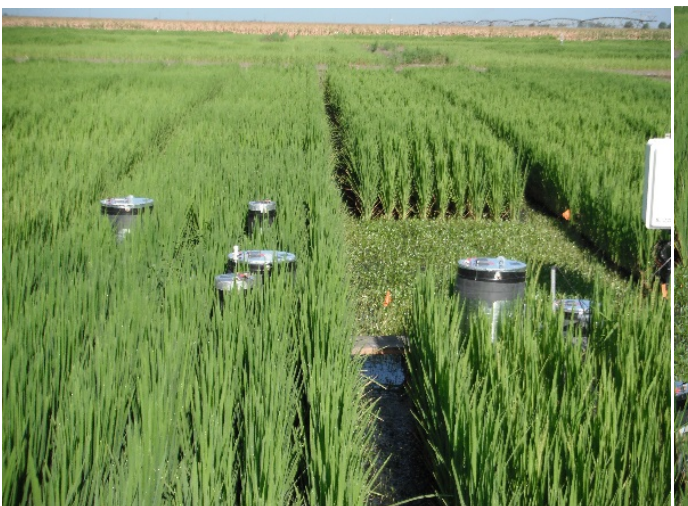

(e)

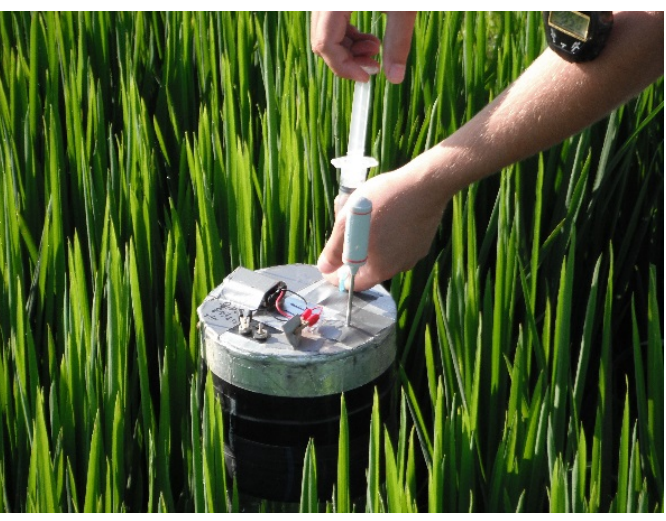

(d)

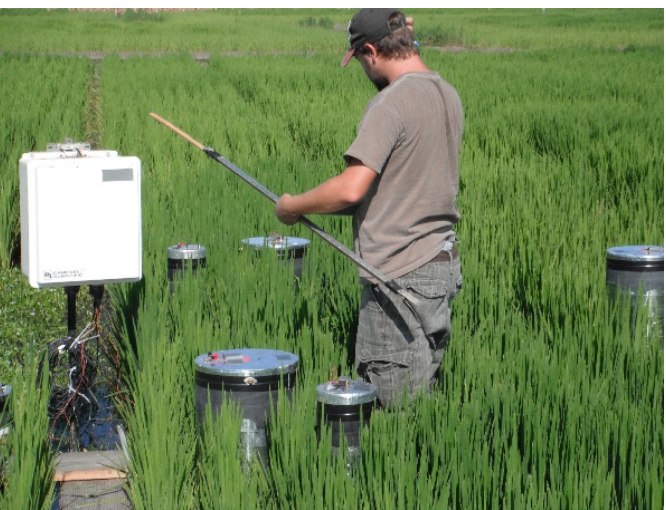

(f)

Figure 1. Selected images of the different chamber sizes in the field. Both chamber sizes win a plot with no rice plants (a). Both chamber sizes in a plot with rice plants (b). Syringe sampling the 30.4-cm diameter chamber through the cap (c). Syringe sampling the 15.2-cm diameter chamber through the cap (d). Both chambers in multiple field plots (e). Both chambers in multiple field plots while measuring the flood depth (f).

Methane fluxes were measured weekly between flood establishment and flood release (i.e., 10 times total) and every other day after flood release (i.e., four times total). Approximately 16 hours prior to sampling, rice plants were carefully bundled together with tie wire prior to installing the chamber extensions. Once the chamber extensions had been set in place, the tie wire was removed to minimize plant disturbance. The following morning, gas sampling occurred between 0800 and 1000 hours. Gas samples were collected from the chamber headspace at 0, 20, 40, and 60 minutes after capping the chamber. A 20-mL B-D syringe (Beckton Dickson and Co., Franklin Lakes, NJ) was inserted into each chamber through the gray butyl-rubber septa at the top of the cap (Figure 
1). After collection of a 20-mL gas sample from the mixed chamber headspace, samples were transferred into pre-evacuated 10-mL, crimp-top glass vials (Agilent Technologies, part \# 5182-0838, Santa Clara, CA). Methane gas standards were also collected in the field following chamber sampling to evaluate potential leakage prior to actual analysis.

Within 48 hours of collection, all gas samples were analyzed on an Agilent 6890-N gas chromatograph (Agilent Technologies) equipped with a flame-ionization detector and a 30-m-long HP-Plot-Q capillary column (Agilent Technologies). Methane concentrations in $\mu \mathrm{L} \cdot \mathrm{L}^{-1}$ were determined by peak-area response from the resulting chromatograms. As described by Parkin and Venterea [7] and according to the Ideal Gas Law, fluxes in $\mathrm{mg} \mathrm{CH} \mathrm{CH}_{4} \mathrm{~m}^{-2} \mathrm{hr}^{-1}$ were calculated by linear regression using the four concentration measurements per chamber and the chamber volume, temperature, and atmospheric pressure measured during sampling. The resulting $\mathrm{r}^{2}$ values from the linear regressions were always greater than 0.9. Linear interpolation between measurement dates was used to calculate season-long $\mathrm{CH}_{4}$ emissions from each chamber.

\subsection{Plant Sampling}

At physiological maturity, all aboveground dry matter (DM) from inside the chambers of both sizes was collected from the vegetated plots. Similarly, plants were cut at the soil surface and collected from one, 1-m row length in each vegetated plot to assess aboveground DM in the bulk plot. All plant samples were dried at $60^{\circ} \mathrm{C}$ for $96 \mathrm{hr}$ and weighed. About three weeks after flood release, panicles from three, 1-m row lengths of rice were hand-harvested from each vegetated plot, dried at $60^{\circ} \mathrm{C}$ for $96 \mathrm{hr}$, manually threshed, and weighed for yield determinations. Yields are reported at a grain moisture content of approximately $120 \mathrm{~g} \cdot \mathrm{kg}^{-1}$.

\subsection{Statistical Analyses}

The effects of vegetation, chamber size, and their interaction on $\mathrm{CH}_{4}$ fluxes throughout the growing season were evaluated by analysis of variance (ANOVA) in SAS (version 9.2, SAS Institute, Inc., Cary, NC) using PROC Mixed based on a RCB split-plot repeated-measures design, where the whole-plot factor was vegetation, the split-plot factor was chamber size, and time was treated as a repeated measure. Due to differences in mechanisms of $\mathrm{CH}_{4}$ release and sampling intervals, flux data were analyzed separately from flooding to flood release and after flood release (i.e., post-flood release). A separate ANOVA was conducted to evaluate the effects of vegetation, chamber size, and their interaction on season-long, area-scaled emissions, post-flood-release emissions, and post-flood-release emissions expressed as a percentage of season-long emissions. In addition, aboveground dry matter was analyzed by ANOVA based on a RCB design with three sampling locations (i.e., inside the 15.2-cm chambers, inside the 30.4-cm chambers, and in the bulk plot). Fisher's protected least significant difference, at the $\alpha=0.05$ level, was used when appropriate for means separations.

\section{Results and Discussion}

\subsection{Methane Fluxes}

Similar to that hypothesized, chamber size did not affect $(P>0.05)$ measured $\mathrm{CH}_{4}$ fluxes between flooding and flood release (Table 2). However, $\mathrm{CH}_{4}$ fluxes differed $(P<0.001)$ between vegetation treatments over time (Table 2). In the first few weeks after flood establishment, averaged across chamber size, $\mathrm{CH}_{4}$ fluxes were low and near zero in both treatments as the soil oxidation-reduction potential was decreasing due to the persistence of the flood. This result is similar to previous observations from a silt-loam soil [9] [10]. In contrast, after about three weeks from flood establishment, averaged across chamber size, the optimally $\mathrm{N}$-fertilized rice consistently maintained greater $\mathrm{CH}_{4}$ fluxes throughout the remainder of the growing season until flood release. This result is also similar to previous observations from a silt-loam soil [9] [10].

Similar to during the flooded period of the rice growing season, after flood release, $\mathrm{CH}_{4}$ fluxes differed $(P=$ 0.007 ) between vegetation treatments over time (Table 2). Averaged across chamber size, a significant postflood-release $\mathrm{CH}_{4}$ pulse (i.e., increased flux) occurred from the bare soil at 5 days after flooding (DAFR), while no pulse occurred from the vegetated treatment (Table 2). However, in contrast to during the flooded period and similar to that hypothesized, $\mathrm{CH}_{4}$ fluxes also differed $(P=0.007)$ between chamber sizes over time (Table 2). Averaged across vegetation treatments, $\mathrm{CH}_{4}$ fluxes from the 30.4-cm chambers were greater than those from the 15.2-cm chambers at 5 DAFR, while fluxes on the other three post-flood-release sample dates were unaffected 
Table 2. Analysis of variance summary of the effects of rice vegetation, chamber size, time, and their interactions on methane fluxes from flooding to flood release and following flood release from a clay soil during the 2012 growing season at the Northeast Research and Extension Center in Keiser, Arkansas.

\begin{tabular}{clc}
\hline \multirow{2}{*}{ Source of Variation } & \multicolumn{2}{c}{ Measurement Period } \\
\cline { 2 - 3 } Vegetation & Flooding to Flood Release & 0.897 \\
Chamber Size & $<0.001$ & 0.320 \\
Vegetation $\times$ Chamber Size & 0.788 & 0.147 \\
Time & 0.795 & 0.001 \\
Vegetation $\times$ Time & $<0.001$ & 0.007 \\
Chamber size $\times$ Time & $<0.001$ & 0.007 \\
Vegetation $\times$ Chamber Size $\times$ Time & 0.773 & 0.183 \\
\hline
\end{tabular}

by chamber size. The chamber-size effect may have been due to differential soil drying that occurred within the base collars of different dimensions. The post-flood-release pulse measured in this study at 5 DAFR was similar to that reported previously from a silt-loam soil [9] [10]. Despite a chamber-size effect on one sample date after flood release, all post-flood-release fluxes were small, $<2.75 \mathrm{mg} \mathrm{CH}_{4}-\mathrm{C} \mathrm{m}^{-2} \cdot \mathrm{hr}^{-1}$. Furthermore, post-floodrelease emissions have been reported to only account for approximately $10 \%$ of the total season-long emissions from a silt-loam soil in eastern Arkansas [9].

Though chamber size did not affect measured fluxes prior to flood release, it is possible that the differing dimensions could have affected the gradient inside the chambers over the 1-hr measurement cycle. If the gradient was affected such that the concentrations leveled off after some time, then the linear regression approach to calculate the chamber flux using the four concentrations measurements may be erroneous. However, in contrast to Rogers et al. [16] where non-linear concentrations were measured at times from a silt-loam soil, none of the measurements from either chamber size in this study exhibited any indication of a non-linear $\mathrm{CH}_{4}$ concentration increase over time (i.e., increasing $\mathrm{CH}_{4}$ concentrations within the chambers did not substantially affect the molecular diffusion gradient). This result indicated that both 15.2- and 30.4-cm diameter chambers appear suitable for measuring $\mathrm{CH}_{4}$ fluxes from flooded rice grown on a clay soil with relatively low resulting season-long $\mathrm{CH}_{4}$ emissions.

\subsection{Seasonal Methane Emissions}

In contrast to that hypothesized, chamber size did not affect $(P>0.05)$ season-long area-scaled emissions, postflood-release emissions, or the post-flood-release emissions as a proportion of total emissions, while vegetation affected both season-long, area-scaled emissions $(P<0.001)$ and post-flood-release emissions as a proportion of total emissions ( $P=0.005$; Table 3$)$. Total season-long, area-scaled $\mathrm{CH}_{4}$ emissions from the optimally $\mathrm{N}$-fertilized rice were 32.6 and $35.6 \mathrm{~kg} \mathrm{CH}_{4}-\mathrm{C} \mathrm{ha}^{-1}$. season $^{-1}$ from the 15.2- and 30.4-cm chambers, respectively, which did not differ and averaged $34.1 \mathrm{~kg} \mathrm{CH}_{4}-\mathrm{C} \mathrm{ha}^{-1} \cdot \operatorname{season}^{-1}$ (Table 4). Furthermore, chamber size did not impact ( $P$ $=0.951$ ) aboveground $\mathrm{DM}$ as $2.71 \mathrm{~kg} \mathrm{DM} \mathrm{m}^{-2}$ accumulated inside the $15.2-\mathrm{cm}$ chambers compared to $2.77 \mathrm{~kg}$ $\mathrm{DM} \mathrm{m}{ }^{-2}$ inside the $30.4-\mathrm{cm}$ chambers, while the bulk plot accumulated $2.83 \mathrm{~kg} \mathrm{DM} \mathrm{m}^{-2}$. Total season-long, area-scaled $\mathrm{CH}_{4}$ emissions from the bare soil were 0.74 and $1.75 \mathrm{~kg} \mathrm{CH}_{4}-\mathrm{C} \mathrm{ha}^{-1}$. season $^{-1}$ from the 15.2- and 30.4-cm chambers, respectively, which did not differ, and averaged $1.25 \mathrm{~kg} \mathrm{CH}_{4}-\mathrm{C} \mathrm{ha}^{-1} \cdot \mathrm{season}^{-1}$, which was significantly lower than that from the optimally $\mathrm{N}$-fertilized rice (Table 4).

The differences in emissions observed between the bare soil and optimally $\mathrm{N}$-fertilized rice were consistent with results previously reported from a silt-loam soil in Arkansas [9] [10]. The similarity in emissions results between chamber sizes indicates that the 15.2-cm diameter chambers adequately facilitated the quantification of $\mathrm{CH}_{4}$ emissions in this study. The post-flood-release emissions as a proportion of total emissions were significantly greater from the bare soil (51\%) than from the optimally N-fertilized rice (2\%; Table 4). This result sup- 
Table 3. Summary of the effects of rice vegetation, chamber size, and their interaction on methane $\left(\mathrm{CH}_{4}\right)$ emissions from a clay soil during the 2012 growing season at the Northeast Research and Extension Center in Keiser, Arkansas.

\begin{tabular}{cccc}
\hline Emissions Property & Vegetation & Chamber Size & Vegetation $\times$ Chamber Size \\
\cline { 3 - 4 } Total Area-Scaled Emissions $\left(\mathrm{kg} \mathrm{CH}_{4}-\mathrm{C} \mathrm{ha}^{-1} \cdot \mathrm{season}^{-1}\right)$ & $<0.001$ & 0.737 & 0.869 \\
Post-Flood-Release Emissions $\left(\mathrm{kg} \mathrm{CH}_{4}-\mathrm{C} \mathrm{ha}^{-1}\right)$ & 0.723 & 0.249 & 0.164 \\
Post-Flood Emissions (\% of Total Emissions) & 0.005 & 0.096 & 0.083 \\
\hline
\end{tabular}

Table 4. Seasonal methane $\left(\mathrm{CH}_{4}\right)$ emissions for unvegetated and high-vegetation rice treatments measured with 15.2- and 30.4-cm inside-diameter chambers from a clay soil during the 2012 growing season at the Northeast Research and Extension Center in Keiser, Arkansas.

\begin{tabular}{|c|c|c|c|}
\hline Property/Chamber Size & Bare Soil & Vegetated & Mean \\
\hline \multicolumn{4}{|c|}{ Area-Scaled Emissions $\left(\mathrm{kg} \mathrm{CH}_{4}-\mathrm{C} \mathrm{ha}^{-1} \cdot\right.$ season $\left.^{-1}\right)$} \\
\hline $15.2-\mathrm{cm}$ & 0.74 & 32.6 & $16.7 \mathrm{~A}^{\ddagger}$ \\
\hline $30.4-\mathrm{cm}$ & 1.75 & 35.6 & $18.7 \mathrm{~A}$ \\
\hline Mean & $1.25 \mathrm{~b}^{\dagger}$ & $34.1 \mathrm{a}$ & \\
\hline \multicolumn{4}{|c|}{ Post-Flood Emissions ( $\mathrm{kg} \mathrm{CH}_{4}-\mathrm{Cha}^{-1}$ ) } \\
\hline $15.2-\mathrm{cm}$ & 0.32 & 0.73 & $0.53 \mathrm{~A}^{\ddagger}$ \\
\hline $30.4-\mathrm{cm}$ & 1.27 & 0.62 & $0.95 \mathrm{~A}$ \\
\hline Mean & $0.80 \mathrm{a}^{\dagger}$ & $0.68 \mathrm{a}$ & \\
\hline \multicolumn{4}{|c|}{ Post-Flood Emissions (\% of Total Emissions) } \\
\hline $15.2-\mathrm{cm}$ & 38.6 & 2.3 & $20.5 \mathrm{~A}^{\ddagger}$ \\
\hline $30.4-\mathrm{cm}$ & 63.5 & 1.6 & $32.6 \mathrm{~A}$ \\
\hline Mean & $51.0 \mathrm{a}^{\dagger}$ & $2.0 \mathrm{~b}$ & \\
\hline
\end{tabular}

${ }^{\dagger}$ Different lower-case letters within a row for a measured property indicate differences among vegetation treatments $(P<0.05)$; ${ }^{\ddagger}$ Different upper-case letters within a column for a measured property indicate differences between chamber-size treatments $(P<0.05)$.

ports previous reports that the presence of the rice plants greatly facilitate passive transport of $\mathrm{CH}_{4}$ from the soil to the atmosphere throughout the flooded portion of the rice growing season [9] [10]. In contrast, $\mathrm{CH}_{4}$ builds up in the soil where rice plants are not present (i.e., the bare-soil treatment in this study) until the overlying floodwater is removed, thus allowing for rapid escape of the entrapped $\mathrm{CH}_{4}$ and the post-flood-release pulse of $\mathrm{CH}_{4}$ observed in this and previously in other studies.

Regardless of chamber size, the magnitude of season-long $\mathrm{CH}_{4}$ emissions measured in this study from a clay soil in northeast Arkansas is low compared to similar studies conducted on silt-loam soils in Arkansas [9] [11]. Furthermore, the average season-long $\mathrm{CH}_{4}$ emissions measured in this study from optimally $\mathrm{N}$-fertilized rice is substantially lower than the US Environmental Protection Agency's reported emissions factor of $178 \mathrm{~kg} \mathrm{CH}_{4}$-C $\mathrm{ha}^{-1}$. season $^{-1}$ for non-California-grown, primary-crop rice production [4].

\section{Conclusion}

Chamber size did not affect $\mathrm{CH}_{4}$ fluxes during the flooded portion of the rice growing season and only affected fluxes on one of four samples dates after flood release. Results indicate that both 15.2- and 30.4-cm diameter chambers were similarly adequate for measuring $\mathrm{CH}_{4}$ fluxes and emissions from the clay soil investigated in this study. Therefore, chamber size does not appear to be an important feature of $\mathrm{CH}_{4}$ emissions studies that would compromise results from relatively homogeneous study areas and/or from soils that have relatively low seasonlong $\mathrm{CH}_{4}$ emissions. If material supplies and/or costs are limiting factors or other logistical constraints require 
diameter-limited chambers, such as for in-row and between-row comparisons, the smaller, 15.2-cm-diameter chamber size may be the more logical choice. When material supplies and/or costs or other constraints are not limiting factors, then the larger, 30.4-cm diameter chambers would likely be preferred.

\section{Acknowledgements}

This research was supported by the Arkansas Rice Research and Promotion Board.

\section{References}

[1] Maclean, J.L., Dawe, D.C., Hardy, B. and Hettel, G.P., Eds. (2002) Rice Almanac: Source Book for the Most Important Economic Activity on Earth. 3rd Edition, CABI Publishing, Wallingford, UK.

[2] Smith, P., Martino, D., Cai, Z., Gwary, D., Janzen, H., Kumar, P., McCarl, B., Ogle, S., O’Mara, F., Rice, C., Scholes, B. and Sirotenko, O. (2007) Agriculture. In: Solomon, S., Qin, D., Manning, M., Chen, Z., Marquis, M., Averyt, K.B., Tignor, M. and Miller, H.L., Eds., Climate Change 2007: The Physical Science Basis. Contribution of Working Group I to the Fourth Assessment Report of the Intergovernmental Panel on Climate Change, Cambridge University Press, Cambridge, United Kingdom and New York, USA.

[3] United States Environmental Protection Agency (USEPA) (2012) Global Anthropogenic Non- $\mathrm{CO}_{2}$ Greenhouse Gas Emissions: 1990-2030. http://www.epa.gov/climatechange/Downloads/EPAactivities/EPA Global NonCO2 Projections Dec2012.pdf

[4] United States Environmental Protection Agency (USEPA) (2014) Inventory of US Greenhouse Gas Emissions and Sinks: 1990-2012.

http://www.epa.gov/climatechange/Downloads/ghgemissions/US-GHG-Inventory-2014-Main-Text.pdf

[5] Forster, P., Ramaswamy, V., Artaxo, P., Berntsen, T., Betts, R., Fahey, D.W., Haywood, J., Lean, J., Lowe, D.C., Myhre, G., Nganga, J., Prinn, R., Raga, G., Schulz, M. and Van Dorland, R. (2007) Changes in Atmospheric Constituents and in Radiative Forcing. In: Solomon, S., Qin, D., Manning, M., Chen, Z., Marquis, M., Averyt, K.B., Tignor, M. and Miller, H.L., Eds, Climate Change 2007: The Physical Science Basis. Contribution of Working Group I to the Fourth Assessment Report of the Intergovernmental Panel on Climate Change, Cambridge University Press, Cambridge, United Kingdom and New York, USA.

[6] Livingston, G. and Hutchinson, G. (1995) Enclosure-Based Measurement of Trace Gas Exchange: Applications and Sources of Error. In: Matson, P.A. and Harris, R.C., Eds., Biogenic Trace Gases: Measuring Emissions from Soil and Water, Blackwell Sciences Ltd., Osney Mead, Oxford, 14-51.

[7] Parkin, T. and Venterea, R. (2010) Chamber-based Trace Gas Flux Measurements. In: Follett, R., Ed., Sampling Protocols, United States Department of Agriculture, Agricultural Research Service, Fort Collins. http://www.ars.usda.gov/SP2UserFiles/Program/212/Chapter\%203.\%20GRACEnet\%20Trace\%20Gas\%20Sampling\% 20Protocols.pdf

[8] Denier van der Gon, H.A.C., Kropff, M.J., van Breemen, N., Wassmann, R., Lantin, R.S., Aduna, E., Corton, T.M. and van Laar, H.H. (2002) Optimizing Grain Yields Reduces $\mathrm{CH}_{4}$ Emissions from Rice Paddy Fields. Proceedings of the National Academy of Sciences, 99, 12021-12024. http://dx.doi.org/10.1073/pnas.192276599

[9] Rogers, C.W., Brye, K.R., Norman, R.J., Gbur, E.E., Mattice, J.D., Parkin, T.B. and Roberts, T.L. (2013) Methane Emissions from Drill-Seeded, Delayed-Flood Rice Production on a Silt-Loam Soil in Arkansas. Journal of Environmental Quality, 42, 1059-1069. http://dx.doi.org/10.2134/jeq2012.0502

[10] Rogers, C.W., Brye, K.R., Smartt, A.D., Norman, R.J., Gbur, E.E. and Evans-White, M.A. (2014) Cultivar and Previous Crop Effects on Methane Emissions from Drill-Seeded, Delayed-Flood Rice Production on a Silt-Loam Soil. Soil Science, 179, 28-36. http://dx.doi.org/10.1097/SS.0000000000000039

[11] Simmonds, M.B., Anders, M., Adviento-Borbe, M.A, van Kessel, C., McClung, A. and Linquist, B.A. (2015) Seasonal Methane and Nitrous Exide Emissions of Several Rice Cultivars in Direct-Seeded Systems. Journal of Environmental Quality, 44, 103-114. http://dx.doi.org/10.2134/jeq2014.07.0286

[12] Soil Survey Staff, Natural Resources Conservation Service, United States Department of Agriculture (2015) Web Soil Survey. http://websoilsurvey.nrcs.usda.gov/app/WebSoilSurvey.aspx

[13] National Oceanic and Atmospheric Administration (NOAA) (2002) Climatography of the United States No. 81: Monthly Station Normals of Temperature, Precipitation, and Heating and Cooling Degree Days 1971-2000. http://www.ncdc.noaa.gov/climatenormals/clim81/ARnorm.pdf

[14] Moldenhauer, K.A.K., Gibbons, J.W., Lee, F.N., Bernhardt, J.L., Wilson Jr., C.E., Cartwright, R.D., Norman, R.J., Blocker, M.M., Ahrent, D.K., Boyett, V.A., Bullock, J.M. and Castaneda, E. (2008) Taggart, High Yielding Large Kernel Long-grain Rice Variety. In: Norman, R.J. and Moldenhauer, K.A.K., Eds., B.R. Wells Rice Research Studies, 
2008, Arkansas Agricultural Experiment Station Research Series, 571, Division of Agriculture, The University of Arkansas System, Fayetteville, 68-73.

[15] Hardke, J.T., Ed. (2013) Arkansas Rice Production Handbook. Misc. Publ. 192. University of Arkansas, Cooperative Extension Service, Little Rock.

[16] Rogers, C.W., Brye, K.R., Norman, R.J., Gasnier, T., Frizzell, D. and Branson, J. (2012) Methane Emissions from a Silt-Loam Soil Under Direct-Seeded, Delayed-Flood Rice Management. In: Norman, R.J. and Moldenhauer, K.A.K., Eds., B.R. Wells Rice Research Studies, 2011, Arkansas Agricultural Experiment Station Research Series, 600, Division of Agriculture, The University of Arkansas System, Fayetteville, 240-247. 